\title{
Exploration and Practice on the Cultivation of Innovative Talents in Local Universities
}

\author{
Guangya Zhang \\ Dean's office \\ Guangdong Ocean University \\ Zhanjiang, China \\ zhangguangya@126.com
}

\author{
Lingli Fan \\ School of ocean and meteorology \\ Guangdong Ocean University \\ Zhanjiang, China \\ fanlingli@126.com
}

\begin{abstract}
To meet the requirement of innovation and entrepreneurship education in universities for the new situation, through the research and literature analysis, some common problems in the reform of innovation and Entrepreneurship Education were found. Guangdong Ocean University changed the concept of education and teaching in time, finished a new toplevel design. Guangdong Ocean University innovation and entrepreneurship training approved by society, because of the use of the following measures: the support system, strengthening the innovation and practice of platform construction, building innovation and entrepreneurship education curriculum system, strengthening teachers' innovation and entrepreneurship education teaching ability, cultivating students' independent thinking and rational judgment.
\end{abstract}

Keywords-Local Universities with industry characteristics; Innovation entrepreneurship education; Personnel training

\section{INTRODUCTION}

The Party Central Committee and the State Department attach importance to innovation and entrepreneurship education in Universities. The eighteenth Congress of the CPC put forward to increase the support of innovation and entrepreneurship training clearly. General Secretary Xi Jinping repeatedly made important instructions to speed up the reform of the education system, to pay attention to the cultivation of students' innovative spirit, to create a large innovation and entrepreneurial talents, which full of innovation and the courage to take the risk. To implement the Party Central Committee's major decisions and arrangements, the general office of the State Council issued "a special opinion, made the system design from the national level, and made a full deployment. Guangdong provincial education department director Luo Weiqi stressed that deepening the reform of the innovation and entrepreneurship education was an urgent need to implement innovation driven development strategy of Guangdong province and the country, was the urgent need to promote industrial restructuring and upgrading, to build an innovative country, to implement the strategy of innovation driven development, was a breakthrough to promote the comprehensive reform of higher education, was an important starting point to improve the quality of personnel training[1]

\section{THE EXISTING PROBLEMS IN THE REFORM OF THE CURRENT INNOVATION AND ENTREPRENEURSHIP EDUCATION}

At present, the talent training of local universities still exists some problem, such as divorcing from social reality to some extent, students' sense of social responsibility, innovative spirit, practical ability remains to be further enhanced, students, families and the community's sense of access to higher education reform is not obvious enough, not strong enough. There are still many problems in the work of innovation and entrepreneurship education. First, the ideological understanding is not fully in place. Some universities carry out innovation and entrepreneurship education as a student or graduate students to do business. Some colleges one-sided to guide students to participate in "Challenge Cup" and other kinds competitions, the contest of innovation and entrepreneurship has become the elite competition, ignore the cultivation of all students' innovative spirit and consciousness [2]. Second policy measures are not perfect. Some universities do not grasp the crux and the key of the investigation, the policy is not specific, lack of relevance, effectiveness. Third is to promote the strength is not enough. Some local universities are still stuck in the meeting, documents and oral, mechanism is not smooth, the management is not deep enough [3].

\section{PRACTICE OF INNOVATION AND ENTREPRENEURSHIP EDUCATION REFORM IN GUANGDONG OCEAN UNIVERSITY}

\section{A. Converting idea, doing a new top-level design, institutional support, collaborative education}

Adhere to the "building university relying on quality, strengthening university relying on talent, revitalizing university relying on science, developing university relying on characteristics" philosophy. Implementing three strategies: connotation development, characteristic development, innovation and development. Based in Guangdong, facing the South China Sea, radiating to the whole country, with the goal of building a high-level university with marine and aquatic characteristics. To cultivate high-quality talents and industry elites with international vision and sense of social responsibility, self-learning ability, practical ability and innovative spirit, and serve the national marine industry and local economy [4]. Always focus on the fundamental task of cultivating noble talents, adhering to the "take student as the foundation, everybody becomes talent" philosophy of 
education. Teaching students in accordance with their aptitude, and further promote the reform of the credit system, giving back the choice right of learning to study, to promote the development of students' personality, promoting the diversification of students. Establishing new concept of innovation and entrepreneurship education, that is "innovation integrating expertise, innovation leading entrepreneurship, entrepreneurship combining into the professional, entrepreneurship driving employment ". Adhere to the "main line", that is, putting the concept of innovation and entrepreneurship education as the main line into the process of personnel training. "Two synergy", that is, the construction of cooperative education mechanism and off campus cooperative education mechanism. "Three in one", that is, "innovation and entrepreneurship teaching + simulation of innovation and entrepreneurship + practice of innovation and Entrepreneurship". Four to shunt, that is, training talents in accordance with the "top notch innovative, complex, application-oriented, international" four directions, corresponding to the student's needs of further study, minor professional double degree study, employment and entrepreneurship and study abroad.

According to the requirements of innovation and entrepreneurship education reform objectives, to start revision of the personnel training program. According to the national standard of undergraduate teaching quality, referencing to the quality standards of enterprises and other industries actively, basing on output oriented education (OBE) concept, the university put the innovation and entrepreneurship education into the process of personnel training. In accordance with the principle "coverage of all, based on professional, the implementation of the classification, strengthen the practice, through the whole process ", constructed innovation and entrepreneurship curriculum by "general education +professional education+ comprehensive practice ".The university organized rewrites of the professional courses syllabus, increased the content of innovation and entrepreneurship education in the professional courses, integrated innovative, critical thinking into knowledge teaching, classroom discussion, course report etc. all links of professional teaching, curriculum evaluation focused on basic knowledge and innovation ability combination. So that students can get innovative training influence from the learning process of professional courses, put the spirit of innovation, entrepreneurship and innovation as an important indicator of entrepreneurial talent training into the curriculum design more clearly.

We are strengthening the cooperation of education within the university, breaking boundaries between colleges, disciplines, and professionals, and building up the mechanism of cooperative education. Basing on the establishment of cultivation and sharing mechanism of high quality curriculum resources, the students can implement the dual degree. The implementation of the "three early", just encourage undergraduate join into a team, a subject, a laboratory as early as. The construction of cooperation education mechanism between other universities, enterprises, local government and overseas universities, the introduction of quality courses, which can attract social resources and foreign high-quality educational resources actively. To strengthen the internationalization of education, to cultivate talents with international competitiveness, by establishing collaborative personnel training mechanism with well-known overseas universities from US, Canada, Taiwan, Hong Kong and so on, carrying out the " $2+2$ ", " $3+1$ " joint training projects.

Setting up innovation and entrepreneurship education leading group, which is led by the principal. The establishment of innovation and entrepreneurship education mechanism led by the department of education, and make concerted efforts of science and technology department, students department, financial department, enrollment and employment guidance center, school committee, and other departments. Bringing the innovation and entrepreneurship education into the important agenda of reform and development, deploying of innovative research work on a regular basis, overall planning educational resources etc. Colleges set up a working group on innovation and entrepreneurship for students, headed by the president, is responsible for the organization and implementation of entrepreneurship work.

Setting up an expert advisory committee on innovation and Entrepreneurship Education, which composed of innovation theory research experts from all sectors of society, business elites and internal teachers, provide overall consulting for the university to carry out innovation and entrepreneurship education, assist in the development of innovation and entrepreneurship education development planning, give assessment and improvement of innovation and entrepreneurship education practice.

Formulating of "the implementation views of the credit system reform of Guangdong Ocean University"," Guiding opinions on the revision of the credit system personnel training program of Guangdong Ocean University ", amending the provisions of credit system management of undergraduate student, promoting the reform of credit system, implementing flexible educational system, extending the length of learning, extending four-years undergraduate period to eight-years. Allowing students to entrepreneurship, and simplifying the necessary procedures. Adopting "Guangdong Ocean University school for full-time undergraduate students turn professional management approach", supporting them to participate in suited professional learning, to provide institutional support for innovation and entrepreneurship students. The evaluation of students' learning is extended from the classroom to the outside, to promote students' active learning and active practice.

\section{B. constructing the curriculum system of innovation and Entrepreneurship Education}

Establishing education reform plan in the university "13th Five-Year" personnel training plan, innovating entrepreneurship education into the process of personnel training. Putting innovation and entrepreneurship education into the process of talent training, primary students focus on stimulating innovation and entrepreneurship awareness, intermediate students focus on improving its ability, senior students focus on its practice. Thinking highly of the main role of professional education in cultivating students' innovation ability and entrepreneurial spirit [5], attaching importance to 
the basic role of the first class in the training of innovation personnel, to promote the organic integration of professional education and entrepreneurship education [6]. According to the basic category, applied professional classification to set up a "three-one" professional innovation and entrepreneurship required courses. To improve the ability of innovation, to explore and enrich the innovation and entrepreneurship education resources, to promote the combination of innovation education and traditional teaching. The "three-one" of the basic specialty is to set up a special subject course of the subject, to complete a professional investigation report, to put forward a creative idea. The "three-one" of application specialty is to set up a business management course, complete a market research report, to submit a business plan. According to the classification principles of implementation, classified design innovation and entrepreneurship practice course in the arts, science and agricultural science, engineering, arts and sports, foreign languages. At the same time, to establish innovation and entrepreneurship education sub professional, innovation and entrepreneurship education experimental classes, etc., to do some targeted training for students.

\section{Constructing the curriculum system of innovation and Entrepreneurship Education}

The teaching effect depends on the teacher's teaching level. Selection and training of teachers is a key problem of the innovation and entrepreneurship education elective courses and required courses for students [7]. The university defined the responsibility of teachers' innovation and entrepreneurship education, improve the professional and technical post evaluation and performance evaluation standards, and strengthen the role of assessment oriented incentives. Actively employing social well-known entrepreneurs, entrepreneurs, experts and scholars, outstanding alumni as part-time business mentor, who guidance and help students to finish entrepreneurial projects. Creating a part-time combination of innovative teaching team by the way of introduction and cultivation. Supporting teachers to participate in the practice of innovation and entrepreneurship in enterprises, research institute, to improve teachers' ability innovation and the ability to guide entrepreneurship for students. Forming an innovation and entrepreneurship teaching team with distinctive professional features, outstanding ability, and industry experts and entrepreneurs willing to participate in it. Research and protection. Based on innovation and entrepreneurship training, to further increase teaching reform and research.

\section{Innovating teaching methods, cultivating students' ability of independent thinking and rational criticism}

In the teaching reform project set up by the school every year, there is a special project "classroom teaching reform", teachers were encouraged to carry out research and Practice on the reform of teaching methods. For example, MOOC, Problem-Based Learning(PBL), Outcome-based Education (OBE), and so on. The theory and practice teaching a specific teaching model: students' learning +classroom teaching and instruction +after-school exercises; the mode of graduation thesis is a topic + reading + writing report and reply, +design or experiment +writing paper [8].
Using of advanced educational technology, giving full play to the advantages of professional discipline construction, introducing shared MOOC, online innovation open courses, offer online courses for students.

Revising "Evaluation and management of teaching quality in Guangdong Ocean University", "Measures for the management of curriculum assessment in Guangdong Ocean University". Giving full play to teachers' leading role and students' subjective position in teaching. The combination of teaching, learning and examination, stimulate the enthusiasm and creativity of students' autonomous learning, promote the coordinated development of students' knowledge, ability and quality, and cultivate the ability of practice and innovation employing social well-known entrepreneurs, entrepreneurs, experts and scholars, outstanding alumni as part-time business mentor, and selecting a hundred business mentor, who guidance and help students to finish entrepreneurial projects. Creating a part-time combination of innovative teaching team by the way of introduction and cultivation. Supporting teachers to participate in the practice of innovation and entrepreneurship in enterprises, research institute, to improve teachers' ability innovation and the ability to guide entrepreneurship for students. Forming an innovation and entrepreneurship teaching team with distinctive professional features, outstanding ability, and industry experts and entrepreneurs willing to participate in it. Research and protection. Based on innovation and entrepreneurship training, to further increase teaching reform and research.

\section{E. Strengthen innovation and entrepreneurship practice and platform construction}

Constructing the teaching chain of "teaching, practice and incubation", there are two levels of university and colleges, three linkages of the student independent practice, the college brand driven, the Pioneering Park incubation, and four major practical platforms of basic experimental platform, professional comprehensive skills training platform, business simulation and business incubation platform. The establishment of college students' entrepreneurship club, regularly held a forum for entrepreneur entrepreneurship salon, and other exchange activities, creating the conditions for students to understand the policy and industry information, learn to accumulate entrepreneurial experience, find partners and investment.

\section{THE EFFECT OF INNOVATION AND ENTREPRENEURSHIP EDUCATION IN GUANGDONG OCEAN UNIVERSITY}

\section{A. Establishing practice base with social forces, to create a diversified platform for innovation and entrepreneurship}

The university established innovation and entrepreneurship incubators for students $\left(800 \mathrm{~m}^{\wedge} 2\right)$, the electricity supplier employment incubator $\left(300 \mathrm{~m}^{\wedge} 2\right)$, university science and technology park (500 $\left.\mathrm{m}^{\wedge} 2\right)$, established "college student collaborative innovation vocational skills training base" in cooperation with the Zhanjiang Municipal Bureau of human resources. In May 2015, our innovation and entrepreneurship incubators was named the Guangdong Provincial Communist Youth League college students "green space" incubator center demonstration; 2015, our employment guidance team was 
named as an outstanding team of college students in Guangdong [10].

\section{B. Driven by project, the implementation of innovation and entrepreneurship training program}

Organizing students to declare innovative entrepreneurship training program every year. There are 863 projects, including 544 provincial projects, 260 national projects, receiving a total funding of $¥ 4020000$ by the end of 2016 . There are 148 national, provincial projects have been completed, 121 papers have been published, 34 patents have been applied, independent or joint application.

\section{To promote learning, organizing academic competition and innovation competition}

The university attaches importance to the student science and technology innovation and entrepreneurship competition and other second classroom activities. Our students had winning in all kinds of entrepreneurial Contest. In Guangdong university entrepreneurship competition "Challenge cup and Create youth", had gained one first-prize, 12 second-prize, 15 third-prize in last three years. Zhanjiang Youjia Network Technology Co. Ltd., an incubating enterprise, had listed in the "Chinese Innovation Board" authorized by the Guangzhou equity trading center.

\section{Innovation and entrepreneurship training has been recognized by the community}

The graduates of our university have a solid foundation, strong practical ability and high comprehensive quality, which has been fully affirmed by the employing units. According to the survey of nearly 600 employers in Guangdong Province, the performance of our graduates is well evaluated in work. $90 \%$ of employers believe that our graduates have good ideological and moral cultivation, dedication and sense of responsibility, a sense of competition, good psychological quality, and good spirit of cooperation.

\section{ACKNOWLEDGMENT}

Fund Projects: Project supported by college teaching quality and teaching reform project construction project in Guangdong, the Education Department of Guangdong province,
2016(233), the construction project of innovation of talent training mode in experimentation area, Innovation and entrepreneurship training mode in Guangdong Ocean University.

\section{REFERENCES}

[1] Luo Weiqi. "the speech in the promotion meeting of innovation and entrepreneurship education reform in Guangdong [EB/OL] ," http://www.gdhed.edu.cn/publicfiles/business/htmlfiles/gdjyt/gdjy/2016 04/497516.html,unpublished. (In Chinese)

[2] Hou yuan, "the speech in the promotion meeting of deepening innovation and entrepreneurship education in regional universities," $\mathrm{http} / / / j y . i m n u . e d u . c n / n 445 \mathrm{c} 11$.jsp, unpublished. (In Chinese).

[3] Liu Yandong, "further promoting the reform and innovation of entrepreneurship education to cultivate public business innovation, in deepening the reform of the innovation and entrepreneurship education in universities forum," [EB/OL],"

http://www.moe.edu.cn/jyb_xwfb/moe_176/201510/t20151026_215488. html,unpublished. (In Chinese).

[4] Notice on the publication of the articles of association of Guangdong Ocean University http://www2.gdou.edu.cn/hdwj/2014/d201475.htm.

[5] Constitution of Guangdong Ocean University, http://www2.gdou.edu.cn/hdwj/2014/d201475.htm,unpublished.(In Chinese).

[6] Zhou Wei,Huang Xiangfang, "the research on the course system of innovation and entrepreneurship education in Colleges and universities,"Jishou University,Cooperative economy and technology, 2012,8.

[7] Chen Baosheng, "the speech in closing meeting of the second session of the China Internet innovation and entrepreneurship competition in Huazhong University of Science and Technology,"[EB/OL]," http://jwc.ncist.edu.cn/article/2016-11-22/art15611.html,unpublished. (In Chinese)

[8] Opinions on strengthening the innovation and entrepreneurship education for undergraduates in Guangdong Ocean University,http://www2.gdou.edu.cn/hdwj/2015/jw2150122.htm,unpubli shed. (In Chinese)

[9] Wang Zhongbing chaired the forum of the Huguang innovation circle planning construction work,

http://news.gdzjdaily.com.cn/zjxw/content/2017/02/05/content_2194070 .shtml(In Chinese)

[10] The work plan of building "Public Entrepreneurship, Innovation" demonstration base in Guangdong Ocean University(20162018),http://www2.gdou.edu.cn/hdwj/2016/zsjy2160019.htm ,unpublish ed. (In Chinese. 